か計画を出してもらって，選択肢を出してもらっ て，それを比較することはできるけれども，費用 便益分析から「こういうものをつくったらいい」 ということは全然出てこないわけです。

最後に法律ですけれども，土地に関するものが 約80本ぐらいあるわけですが，これを実効性のあ るものにするためには，まず建築主事が調べない といけないのですが，日本には 2000 人しかいない わけです。不景気でも， 1 年間に100万戸から 120 万戸の家が建つわけなので, 2000 人で割ると， 1 人で 1 年間に 600 軒も調べなきゃだめで,こんなバ カなことはできないです。以上です。

三 橋：秋山先生, いかがですか。

秋 山：私の「財源確保」という意味は，お金が あれば解決するということじゃなくて，まさに おっしゃるとおり，土地そのものが完全に私有化 されることによって経済効率が良くなり，市場は 活性化するんだけれども，言ってみれば，お金で それだけ公共空間あるいは緑地は奪われているん じゃないかと思います。少なくともそういう力に 対して，たとえば緑地でなくなろうとしているも のを，ある程度のコンセンサスでとどめる，それ を買収して，より公共的なものにストックしてい くという力を持たないと……方で, きわめて大 きな「経済」という力で緑地が奪われていってい るわけですから，それに対して基本的には経済活 動の中で，発展すれば発展するだけ，負の効果を ある程度あがなえるような意味での財源確保とい うことを申し上げたつもりです。

ですから，たとえば中国ではいま経済活性化と いうことで「土地市場」なんて言っておりますけ れども，あちらの開発当局の人に架に聞いてみる と，ぜんぜん意味が違って，土地は使用権として の価格が付いているだけであって，決してこれを 転売したりする処物権を許容するものではないと いうので，そういう点ではまことにうらやましい と思いますし，ヨーロッパの先進各国でも私有権 を完全に, 絶対的に認めてはいないところに日本
との違いがあると，つくづく感じる次第でありま す。

三 橋：いま税あるいは法律のご質問が出ました ので，工学 (建築) 関係で芝浦工業大学教授で建 築学会にも所属されている南一誠先生にコメント をお願いします。

南：簡単にお話をさせていただきます。一人一人 の土地の所有者あるいは企業が, 公共空間あるい は緑地が必要だとわかっていても, それぞれの置 かれた立場で最善の選択をしており，それを積み 重ねると，今日あるような姿になってしまう。こ れは社会システムとして再デザインが必要なとき が来ているのではないか。建築学会としてもそう いう問題意識を持って, 近しい不動産学会とか都 市計画学会とか土木学会に声をかけて, 一緒に研 究をしてきたわけですけれども, きょう，この場 で確認できたように，それだけではかなり不足を していて, 経済あるいは法律といった, もっと幅 広い分野の方と一緒にこの研究を進めなければい けないということを認識した次第です。

したがって，先ほどお話がありましたように， 建築学会は少しハードに寄った領域であるので, 社会科学との接点に不動産学会にこうやって入っ ていただいて，議論をつないでいっていただいた のは大変ありがたく，感謝申し上げる次第です。 三 橋：それでは，まだあろうかと思いますが, 定刻の時間をもう過ぎておりますので，ここで熊 田先生に総括をお願いしたいと思います。

\section{総括 公共空間を考えるPEAT}

熊 田：非常に活発で面白い創造的な議論があり ました。全体を一言でいえば，国民の心の中にあ る公共空間のイメージの良いところが合成され共 有化された形で政策に乗れば，いい公共空間が出 現します，ということでした。他分野の研究者と 連携で良い公共空間を形成する理論をつくってい きたいとをおっしゃった。本当にそんなにうまく いくのかということですが，公共空間を決める決 
定の方法というのは（ここに専門家がおりますし， 会場にもおられる)，「公共選択」という方法です。 ただ，日本の公共選択は経済学部の演習課題だと いわれているのですが，私はそれは間違いだと 思っていますが，公共選択の方法論をいろいろ研 究してみると, PとEとAとTというキイとなる文 字がうかびます。座長の三橋先生から始まって, パネリストの発言が私の心の中の鏡に「PEAT」 がどういう形で映ったかというお話で総括をさせ ていただきます。

文系の大学の教授として学のあるところをご披 露申し上げますが，日本で初めて文字として「大 和魂」という言葉を使ったのは紫式部だというこ とをご存じの方は，この会場には半分ぐらいおら れるのかもしれません。ところが，それは当時の 宮中で起こっていた大学改革とリンクされており ましてた。その「大和魂」という言葉は大和の人 たちの文化的な活動がおりなすの歴史の流れ，そ してそのなかで形成されるのたたずまいを大和の 文化でつくられた自分に固有の魂に写し取る，と いうこと，文化や歴史の認識装置として意味でつ くられた言葉です。その魂を磨くために学問所で 学問をする，それが大学という場であるという定 義なのです。

すばらしいですね。こういう定義を紫式部がし ていたということを振り返ってみて，いまの 「PEAT」の話に行くんですが，私が最近ヨーロッ パのある学者と議論をした問題の一つは, きょう の議論と関係があります。関西のほうで電車がぶ ち当たった，あのマンションです。あの鉄道は, なぜあんな速度が可能な状態にしてあったのか。 あそこになぜマンションを建てることができたの かというのが，彼らの疑問でした。きょうの議論 は，実はそこに関係していると思っております。

都市計画で，あそこにマンションを建てちゃい けないぞ，建築基準法で，あんなものは建てさせ ないぞ，スピード制限で，あそこは市街地内部の 鉄道なんだから，都市間鉄道ではないぞ，だから，

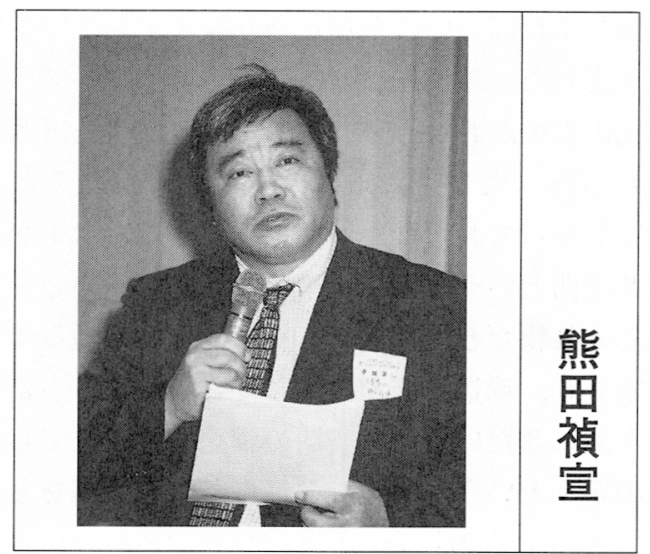

アーバン・マネジメントとしては $50 \mathrm{~km}$ 以出した ら逮捕する，というぐらいのことでやっておけば よかった。……あのンションの住民は本当に被 害者なのかというのが，彼らが提示した疑問だっ たわけです。

われわれが公共スペースの問題を議論するとき には，そういう問題がいっぱい絡んでいるなとい うことで，自分の魂が本当に多くの人々の生活の 安心や安心を論じるにたる全体の公共スペース問 題を写し取れるのだろうか。学問所でもう一度, 魂をお互いに磨こうではありませんか。この学会 も，大和魂を磨く学問所の一つになりたいものだ と思いながら話しをきいていました。

あとは急ぎます。なぜPEATという表現になっ たかは，懇親会で質問をされるか，「バカ」と言っ ていただければ結構です (笑)。

三橋先生の括話からは, Pは「パブリック (Public)」という言葉が浮かびました。要するに， パブリック，都市計画にはいろんなエンジニアリ ング (Engineering) が関係していて，エンジニ アリングのいろんな分野の人たちが仕事を分担し 合う必要のあるアサインメント (Assignment) で す。それで，公共空間をタスク（Task）としてつ くり上げれば，何とかなるかなという意味合いで (これは学術会議が言っているんですが), 設計科 学としての新しいあり方をタスクとして私たちは 
議論をすればいいのかなというニュアンスで受け 取りました。三橋先生のPEATです。

秋山先生が扔っしゃっていたことは（先ほど会 場からあったコメントは，まったく逆のことを おっしゃっておられたと私は理解したんですが)， 公共空間というものは本来, 多くの人々の心を入 れる入れ物だと考えたい。それを車両が通るよう な物入れ，輸送空間だけにしておいて，本当に都 市を論じるだけの公共空間の議論を組み立てられ るのか? というこれまでの都市計画に異議をとな えられた。その場合のPはパワー (Power) とか …...ただ，パワーの背景にPeopleの問題を考えざ るを得ないということをおっしゃっていたわけで す。Eはエコロジー (Ecology) のことを明確に おっしゃっておられたと思いますが, 街に建って いる建物はアセット（Asset）, 資産じゃないぞ, Architectureで，これは美の問題，アート（Art） の問題なんだということもおっしゃった，最後に， Architectureのフィールドで育ったテクノロジー (Technology) をもう少し活用して欲しいと主張 された。これが秋山先生のPEATです。

駒井先生にとってはポリシー公共空間は（Policy）の成果としてとらえる，ただ，そこにはパブ リック・チョイスの話が出てきましたから，Pは 必ずしもポリシーという用語だけじゃないんです が，どうもポリシーの執行母体としたガバメント を意識しているというニュアンスのことがかなり あったように思っておりますパブリックとこのガ バメントの関係のあり方が問題でしょう。 Eは明 らかにエコノミックス (Economics) ですね。駒 井先生がそれほどエコノミックスの信奉者だとは, 私, 理解してなかったんですが, 最近, 教授にし てもらったので，お礼のつもりでエコノミックス を強調しておられるのかな, ちょっとやり過ぎで はないかな（笑）という受け取り方をしました。 Aのほうはアメニティ (Amenity) とかアセスメ ント (Assessment) のことを盛んに言っておられ ましたし，トータル・アウトカム（Total outcome）
ということを考えないで，まちがつくれるわけが ないじゃないかと言っておられて，それは「フ リー・ランチなし」ということで言えば,タックス・ システム（Tax System）のリデザインを考えざる を得ないのかなというニュアンスの発言もされた と思っております。ただ，経済がわからないとい うことと社会的にわからないのだということがイ コールのような発言があって, それはちょっと違 うかなという気がしておりました。これが，いさ さか重複もありますが，駒井先生のPEATです。

中井先生のPは, 何度聞いても, これはパブリッ クも入っているんですけれども, プランニング (Planning) です。「プランニング至上主義」とま では，あえて言いませんが，私もかつて中井先生 の同僚として, 日本一のプランニング・スクール をつくるぞということで長い間努力してきたつも りなので，プランニング至上主義になって当然だ と思いますが，ただ，その「プランニング」の概 念自体は新しい時代に合わせて考えていっていた だいているやに受け取りました。Eのほうは，先 生が挙げられた幾つかの文字を拾っているんです が，Effectivenessとかいう言葉が浮かぶ使い方を しておりました。Aでは, AccessibilityとかAmenityに結びつく発言をしておられます。Tに関し ては，市民同士の信頼関係，市民と政府，公共部 門の信頼関係ということで，トラスト (Trust) という言葉を割り当てておきます。中井先生の PEATはこうなりました。

公共空間の利用者はジェネラル・パブリックで あることを，いちばん明確におっしゃった。設計 者とか, それの設置のあり方を決めるのは産官学 の連携による理論や技術が中心で, 理論無視で市 民が登場したら許さないという感じに聞こえてし まった。市民はおそらく理論を無視する権限も 持っているんじゃないか。電車が外れて, ぶち当 たってくれば，そこで電車の人たちが全滅するの を覚悟の上であの建物を建てたのは，市民の情念 です。あれは悪とだけは言えないでしょう。ただ, 
本当の被害者は誰なのか，まだわかってないと私 は思っています。

丸山先生はいろんなことをおっしゃっておられ たんですが，要するに，日本の中では市民の発想 や要求を公的にきちんと議論をする習慣すら，つ いてないじゃないかというニュアンスの発言が繰 り返しあった。公共空間のあり方を議論するとき にパブリック・プレッシャー(Public Pressure), が もうちょっと明白に作動するような形で, 法の運 用がうまく使えるような考え方ができないかとい うご提案に近い発言と受け取りました。環境の問 題に関してはEnduranceといいますか, 受忍限度 論で考える。ただ，受忍限度論で日本は少し問題 を起こしているような気がします。今度も福岡高 裁が, 諫早湾でムッゴロウや貝が生きられるよう にしようという一審の判決をひっくり返しちゃっ たわけですね。あれは海水が出入りできるように してくれたほうが，私なんかは受忍できる。いま は現在に生きている人々による受忍限度論だけで は環境問題は議論できないように私は思っており ます。それで，いろんな議論をするのに，いろん な主体が公的に有効な結論を合意として導き出す 方法を（この言葉を先生はおっしゃいませんでし たけれども)

Arbitrationにもうちょっと入れたいとおっ しゃった。ただ，公共空間には（最後のほうにこ の議論が出たのですが), パブリック・スペースと して良い管理をする主体がまだ見つかってない。 テリトリー (Teritory) として，「俺のものだ」と みんなが了解しやすいような形ではないかという ことを言っておられたような気がします。ただ， いずれにしろ, 日本の法体系はパブリック・スペー
スをうまくつくったりマネージしたりするのには 民意も法律も行政も未熟じゃないか不合格点を丸 山先生は出された。これが丸山流法学のPEATで す。

きょうは学会長がたくさんいるぞという中の一 人として，私もいま別の学会の会長をしておりま して，「石を投げれば会長に当たる」というような シンポジウムになりましたが (笑), 私の磨きの足 りない心の中に映った $\mathrm{P}, \mathrm{E}, \mathrm{A}, \mathrm{T}$ で皆さんの発 言の特徴づけを無理やりさせていただきました。 「私のPEATを述べてしめくくりとういたします が，公共空間づくりの公共選択の場が持つべき性 質として述べますと，1）市民参画（participation)，2）有効な討論 (effective discussion), 3 ）選択の説明責任 (accountability)，そして 4) 決定過程の透明性（transparency）と考えており ます。これらはゴールとして考える基準でまだ満 たされていないのは今日の論者の議論からも明ら かです。今日の討論は大変に思考を刺激する有用 な成果を残して下さったと思います。ありがとう ございました。

三 橋：どうもありがとうございました。ちなみ に, 熊田先生は不動産学会の前会長で, 現在は日 本地域学会の会長であります。

最後にすばらしい総括をしていただきました。 これに反論のある方は，ぜひ懇親会であの大きい 体にぶつけていただきたいと思います。

長時間，会場の皆さんには参加していただきま して，本当にありがとうございました。また，パ ネリストの皆さんもありがとうございました。(拍 手) 